\title{
Nutritional status and dietary practices of 4-24-month-old children from a rural South African community
}

\author{
Mieke Faber* and AJS Benadé \\ National Research Programme for Nutritional Intervention, Medical Research Council, \\ Parow, South Africa
}

Submitted 15 September 1998: Accepted 23 November 1998

\begin{abstract}
Objectives: To assess the nutritional status and dietary practices of 4-24-month-old children (under-twos) in a rural South African community.

Design: Cross-sectional survey.

Setting: A low socioeconomic rural African community (Ndunakazi), approximately $60 \mathrm{~km}$ north-west of Durban, KwaZulu-Natal, South Africa.

Subjects: Children $(n=115), 4-24$ months old who attended growth monitoring posts in the area.

Results: Of these under-twos, 37.3\% had low vitamin A status (serum retinol $<20 \mu \mathrm{g}$ $\mathrm{dl}^{-1}$ ), 65.2\% were anaemic, $43.2 \%$ had serum ferritin levels $<10 \mu \mathrm{gl}^{-1}$ (an indicator of low iron stores) and $15.3 \%$ were stunted. Breastfeeding was initiated by $99 \%$ of mothers. At the time of the survey, $80 \%$ of infants in the $4-12$-month-old category and $56.9 \%$ of children in the $12-24$-month-old category were being breastfed. Solid foods were introduced at $3.6 \pm 0.8$ months. Food intake reflected a high intake of carbohydrate-rich foods, and irregular intakes of fruit and vegetables, especially those rich in vitamin A. Foods of animal origin were not consumed regularly. Of these under-twos, 15.9\% experienced an episode of diarrhoea during 2 weeks prior to the survey.

Conclusion: These under-twos had a poor vitamin A and iron status. Nutrition education, intervention programmes and feeding schemes should address micronutrient deficiencies, with the focus on the quality of the diet, rather than quantity.
\end{abstract}

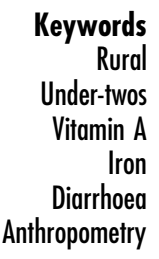

In South Africa malnutrition has two components, namely chronic diseases of lifestyle (typically in adulthood) and undernutrition (typically in pregnant and lactating women, and infants and young children). Women and children are amongst the most vulnerable groups in the country ${ }^{1}$. According to international criteria $^{2}$, the national prevalence (one in three children under 6 years) of vitamin A deficiency (serum vitamin A $<20 \mu \mathrm{g} \mathrm{dl}^{-1}$ ) identifies South Africa as having a serious health problem of vitamin A deficiency. Often undernutrition occurs at an early age; as for anaemia and poor iron status, children in the 6-23-month age group are the most severely affected. In terms of stunting, rural communities are more severely affected than urban communities ${ }^{3}$. Of the entire population $53 \%$ live in rural areas, the vast majority of whom are poor ${ }^{1}$. In some rural areas the bulk of the diet is refined maize meal and bread ${ }^{4}$. Results of a meta-analysis showed that the micronutrient intakes of many population groups in the country were far from optimal ${ }^{5}$.

The South African government (through the Department of Health) is committed to develop and implement an integrated nutrition strategy targeting children $^{1}$. The identification and recognition of malnutrition in preschool children as a problem of public health importance calls for documentation of data on and factors relating to the nutritional status of preschool children in various geographical areas.

The aim of this study was to assess the nutritional status and dietary practices of children between 4 and 24 months of age (under-twos) from a low socioeconomic rural community in KwaZulu-Natal, South Africa, by looking at micronutrient, haematological, anthropometric and dietary indicators.

\section{Subjects and methods}

\section{Population}

The study population is a rural community in KwaZuluNatal, South Africa, situated approximately $60 \mathrm{~km}$ north-west of the Durban coastline. A situation analysis revealed that problems encountered in the area are typical of South African rural areas, and include a lack of clean water, municipal and health services, a sanitation system and electricity; large families (41\% of mothers have five or more children); illiteracy 
and unemployment. Working men are mainly migrant labourers, only going home for weekends (unpublished data, source, Oelofse, 1994).

The prevalence of low birth weight in the area is estimated at $8.1 \%$ (unpublished data, source, Oelofse, 1994). Previous data ${ }^{6}$ showed that $32 \%$ of mothers had lost a child before the age of 5 years; most of these children (64\%) died during their first year of life. Diarrhoea was given as the main cause of death.

\section{Sampling and etbics}

All children between 4 and 24 months old who attended growth monitoring posts (called Isizinda) ${ }^{6}$ in the area were recruited. (From data obtained from house-to-house visits, it is estimated that most children attend the Isizinda.) The response rate was $79.3 \%$. The sample consisted of 115 children $(50.9 \%$ boys and $49.1 \%$ girls).

Ethical approval was obtained from the Ethics Committee of the Medical Research Council. Written informed consent was obtained from the mother or guardian. The interviews and anthropometric measurements were carried out by nutrition monitors who were trained for the project.

\section{Antbropometry}

Anthropometric evaluation of the nutritional status of the children took place at the Isizinda. Children were assessed with regard to body weight and length as described by Jelliffe and Jelliffe ${ }^{7}$. Weight was measured to the nearest $0.05 \mathrm{~kg}$ on a load cell operated digital scale (UC-300 Precision Health Scale). Recumbent body length was measured to the nearest $0.1 \mathrm{~cm}$ on a horizontally placed measuring board. Date of birth and birth weight were obtained from the child's health card.

\section{Medical record}

Morbidity data was collected for each child. This information was obtained from the mother or caretaker by the nutrition monitor during the child's monthly visit to the Isizinda. The mother/caretaker was asked whether the child had experienced diarrhoea, defined as passing three or more loose watery stools day ${ }^{-1}$, during the last 2 weeks. The number of episodes, number of days episode ${ }^{-1}$, dietary changes and treatment given were recorded.

\section{Breastfeeding and complementary feeding practices}

Breastfeeding and complementary feeding practices were determined by questionnaire. The frequency of the consumption of prespecified food items were recorded for the previous month. The questionnaire made provision for food items consumed but not listed. The food items listed were selected from information collected beforehand by questionnaires, observation and informal interviews. Frequency of consumption was recorded selecting one of the following five options: every day, most days (not every day, but at least 4 days week ${ }^{-1}$ ), once a week (less often than 4 days week ${ }^{-1}$, but at least once week ${ }^{-1}$ ), seldom (less than once week $^{-1} /$ infrequently), and never. Food intake was not quantified.

\section{Haematological and biochemical status}

Blood $(5 \mathrm{ml})$ was obtained by antecubital venepuncture. A full blood count was performed within $8 \mathrm{~h}$ by means of an automated cell counter (Coulter STKS, Florida, USA) on an aliquot of fresh blood. The remainder of the blood was centrifuged to separate serum and red cells. Serum was stored at $-80^{\circ} \mathrm{C}$ until analysed. Serum ferritin was determined by an immunoradiometric assay (Ferritin Mab Solid Phase Component System, Becton Dickinson and Co., USA), using an Auto Gamma 500C counting system from United Technologies Packard (USA). Plasma retinol was determined by using a slightly modified version of the reversed-phase high-performance liquid chromatography (HPLC) method as described by Catignani and Bieri ${ }^{8}$.

\section{Haematological, biochemical and antbropometric reference values}

Low iron stores were defined as serum ferritin levels ${ }^{9}$ less than $10 \mu \mathrm{gl}^{-1}$ and anaemia was defined as haemoglobin levels less than $11 \mathrm{~g} \mathrm{dl}^{-1}$. The severity of anaemia was classified as mild (10.0-10.9 $\left.\mu \mathrm{g} \mathrm{dl}^{-1}\right)$, moderate $\left(7.0-9.9 \mu \mathrm{g} \mathrm{dl}^{-1}\right)$, severe $\left(4.0-6.9 \mu \mathrm{g} \mathrm{dl}^{-1}\right)$ and very severe $\left(<4.0 \mu \mathrm{g} \mathrm{dl}^{-1}\right)^{10}$. A white blood cell (WBC) count $>17.7 \times 10^{9} 1^{-1}$ is an indication of infection ${ }^{11}$. Serum retinol levels $>30 \mu \mathrm{g} \mathrm{dl}^{-1}$ were considered as adequate, between 20 and $30 \mu \mathrm{g} \mathrm{dl}^{-1}$ as marginal, between 10 and $20 \mu \mathrm{g} \mathrm{dl}^{-1}$ as low and $<$ $10 \mu \mathrm{g} \mathrm{dl}^{-1}$ as deficient ${ }^{12}$. Anthropometric variables were analysed according to National Center for Health Statistics (NCHS) reference values as prescribed by the NCHS/World Health Organization (WHO) ${ }^{13}$.

\section{Statistical metbods}

Anthropometric indicators, namely weight-for-age, height-for-age and weight-for-height were converted to Z-scores (HAZ, WAZ and WHZ, respectively) based on reference material in the program package Epi Info version 5. The data was analysed using univariate and frequency analysis, and analysis of variance through the SAS statistical package, release 6.03 edition, 1988 (SAS Institute Inc., Cary, NC, USA) The results are presented either as the means and standard deviations (SD) or as proportions (\%). The children are grouped into two age categories, 4-12 and 12-24 months. Statistical significant differences 
between these two groups were tested for using analysis of variance.

\section{Results}

The mean age of the children was $14.5 \pm 5.8$ months. Birth weights were not available for the $24.8 \%$ of children who were born at home (home deliveries). Of the 87 children who were born in a hospital, birth weights were available for 82 children. The prevalence of low birth weight $(<2500 \mathrm{~g})$ for these babies was $7.3 \%$.

Of the total sample of 115 children tested, the serum ferritin levels of four children and the serum retinol levels of five children were not available. The mean blood values are given in Table 1. There was no significant difference in the mean serum ferritin levels across the age range of subsamples at 4-12 and 12-24 months. Children in the 12-24-month age category had higher levels of haemoglobin $(P=0.0005)$ and serum retinol $(P=0.0395)$ than children in the 4-12month age category. The prevalence of micronutrient deficiencies is given in Table 2. Anaemia (haemoglobin $<11 \mathrm{~g} \mathrm{dl}^{-1}$ ) was present in $65.2 \%$ of the under-twos, $37.3 \%$ had low serum retinol levels $\left(<20 \mu \mathrm{g} \mathrm{dl}^{-1}\right)$ and $43.2 \%$ had serum ferritin levels below $10 \mu \mathrm{gl}^{-1}$ (an indication of low iron stores).

Anthropometric indicators are shown in Table 2. The mean Z-score (which is a representation of how many standard deviations the mean deviates from the

Table 1 Mean and standard deviations (SD) for blood values; for the total group as well as for the two age categories separately

\begin{tabular}{lcccc}
\hline & All & $4-12$ months & $12-24$ months & $n=72$ \\
& $n=115$ & $n=43$ & $11.2(3.5)$ & NS value \\
\hline White blood cell count $\left(\times 10^{9} \mathrm{I}^{-1}\right)$ & $11.4(3.3)$ & $11.7(3.0)$ & $10.7(1.0)$ & 0.0005 \\
Haemoglobin $\left(\mathrm{g} \mathrm{dl}^{-1}\right)$ & $10.5(1.1)$ & $10.0(1.0)$ & $12.0(8.4)$ & NS \\
Serum ferritin $\left(\mu \mathrm{g} \mathrm{I}^{-1}\right)$ & $12.5(9.6)$ & $13.3(11.4)$ & $23.1(6.6)$ & 0.0395 \\
Serum retinol $\left(\mu \mathrm{g} \mathrm{dl}^{-1}\right)$ & $22.2(6.3)$ & $20.5(5.6)$ & \\
\hline
\end{tabular}

* Statistical significance (analysis of variance) between the two age categories.

Table 2 Prevalence of micronutrient deficiencies and anthropometric indicators for the total group and per age category

\begin{tabular}{|c|c|c|c|}
\hline & $\begin{array}{c}\text { All } \\
n=115\end{array}$ & $\begin{array}{c}4-12 \text { months } \\
n=43\end{array}$ & $\begin{array}{c}12-24 \text { months } \\
n=72\end{array}$ \\
\hline White blood cell count $>17.7 \times 10^{9} \mathrm{I}^{-1}$ & $4.4 \%$ & $2.3 \%$ & $5.6 \%$ \\
\hline $\begin{array}{l}\text { Haemoglobin } \\
<11.0 \mathrm{~g} \mathrm{dl}^{-1} \\
10-11.0 \mathrm{~g} \mathrm{dl}^{-1} \\
7-10 \mathrm{~g} \mathrm{dl}^{-1} \\
4-7 \mathrm{~g} \mathrm{dl}^{-1}\end{array}$ & $\begin{array}{r}65.2 \% \\
29.6 \% \\
34.8 \% \\
0.9 \%\end{array}$ & $\begin{array}{r}83.7 \% \\
34.9 \% \\
46.5 \% \\
2.3 \%\end{array}$ & $\begin{array}{r}54.2 \% \\
26.4 \% \\
27.8 \% \\
0.0 \%\end{array}$ \\
\hline $\begin{array}{l}\text { Serum retinol } \\
<10 \mu \mathrm{g} \mathrm{dl}^{-1} \\
10-20 \mu \mathrm{g} \mathrm{dl}^{-1} \\
20-30 \mu \mathrm{g} \mathrm{dl}^{-1} \\
30 \mu \mathrm{g} \mathrm{dl}^{-1}\end{array}$ & $\begin{array}{r}0.0 \% \\
37.3 \% \\
50.9 \% \\
11.8 \%\end{array}$ & $\begin{array}{r}0.0 \% \\
48.8 \% \\
46.3 \% \\
4.9 \%\end{array}$ & $\begin{array}{r}0.0 \% \\
30.4 \% \\
53.6 \% \\
15.9 \%\end{array}$ \\
\hline Ferritin $<10 \mu \mathrm{gl}^{-1}$ & $43.2 \%$ & $40.5 \%$ & $44.9 \%$ \\
\hline Anthropometric indicators & & & \\
\hline $\begin{array}{l}\text { Height-for-age (HAZ) } \\
\text { mean } \\
\text { standard deviation } \\
\text { percentage }<2 \text { SD (stunting) }\end{array}$ & $\begin{array}{r}-1.13 \\
0.96 \\
15.3 \%\end{array}$ & $\begin{array}{r}-1.17 \\
0.97 \\
17.4 \%\end{array}$ & $\begin{array}{r}-1.09 \\
0.96 \\
13.8 \%\end{array}$ \\
\hline $\begin{array}{l}\text { Weight-for-age (WAZ) } \\
\text { mean } \\
\text { standard deviation } \\
\text { percentage }<2 \text { SD (underweight) }\end{array}$ & $\begin{array}{c}-0.21 \\
1.06 \\
3.6 \%\end{array}$ & $\begin{array}{c}-0.16 \\
1.07 \\
4.4 \%\end{array}$ & $\begin{array}{c}-0.24 \\
1.07 \\
3.1 \%\end{array}$ \\
\hline $\begin{array}{l}\text { Weight-for-height }(\mathrm{WHZ}) \\
\text { mean } \\
\text { standard deviation } \\
\text { percentage }<2 \mathrm{SD} \text { (wasted) } \\
\text { percentage }>2 \text { SD (overweight) }\end{array}$ & $\begin{array}{l}0.72 \\
1.01 \\
0.9 \% \\
7.2 \%\end{array}$ & $\begin{array}{c}0.93 \\
0.96 \\
0.0 \% \\
10.9 \%\end{array}$ & $\begin{array}{l}0.57 \\
1.02 \\
1.5 \% \\
4.6 \%\end{array}$ \\
\hline
\end{tabular}


median of the NCHS reference population) of the height-for-age index was a negative value, indicating that this index of malnutrition in this study was shifted towards low, or undernourished, levels.

Of the under-twos, 15.9\% reported an episode of diarrhoea in the 2 weeks prior to the survey. The mean duration of such an episode was $6.2 \pm 4.1$ days. For most (77.7\%) of these children the episode lasted 4 days or more.

Breastfeeding was initiated in $99 \%$ of the sample. At the time of the survey $80 \%$ of infants in the 4-12-month age category and $56.9 \%$ of children in the $12-24$-month age category were still being breastfed. More than $60 \%$ of the infants were introduced to water during the first month of life (1 week: 46.5\%; 2 weeks: 8.9\%; 3 weeks:
4.0\%; 4 weeks: $2.0 \%$ ). At the time of the survey, $18.5 \%$ of the under-twos received either formula milk or milk powder feeds (similar percentage in both age categories). Fresh milk was seldom consumed. Solid foods were introduced at a mean age of $3.6 \pm 0.8$ months. The majority (95\%) of infants were introduced to solid foods at 4 months or younger (2 months: $4 \%$; 3 months: 40\%; 4 months: 51\%). The most popular first solid food was maize meal porridge (85.1\%). At the time of the survey, only $2.8 \%$ of the under-twos ate a cooked porridge other than maize meal porridge, while commercially available infant cereals were consumed by $11 \%$ of children. The percentage distribution of children in relation to the frequency of consumption of different food items is shown in Table 3. Foods of

Table 3 Percentage distribution of children in relation to the frequency of consumption of different food items. The data is presented for two age categories, 4-12 months and 12-24 months, respectively

\begin{tabular}{|c|c|c|c|c|c|c|}
\hline & Age group (months) & Every day & Most days & Once/week & Seldom & Never \\
\hline \multicolumn{7}{|l|}{ Foods of animal origin } \\
\hline \multirow[t]{2}{*}{ Meat } & $4-12$ & & 2.0 & 30.0 & 22.0 & 46.0 \\
\hline & $12-24$ & & 3.5 & 72.4 & 17.2 & 6.9 \\
\hline \multirow[t]{2}{*}{ Chicken } & $4-12$ & & 0.0 & 38.0 & 16.0 & 46.0 \\
\hline & $12-24$ & & 5.2 & 67.2 & 22.4 & 5.2 \\
\hline \multirow[t]{2}{*}{ Fish } & $4-12$ & & & 0.0 & 48.0 & 52.0 \\
\hline & $12-24$ & & & 10.3 & 65.5 & 24.1 \\
\hline \multirow[t]{2}{*}{ Eggs } & 4-12 & & 0.0 & 2.0 & 60.0 & 38.0 \\
\hline & $12-24$ & & 3.5 & 12.3 & 78.9 & 5.3 \\
\hline \multicolumn{7}{|l|}{ Carbohydrate-rich foods } \\
\hline \multirow[t]{2}{*}{ Bread (white, brown, commercial, homemade) } & $4-12$ & 4.0 & 54.0 & 10.0 & 6.0 & 26.0 \\
\hline & $12-24$ & 21.0 & 64.9 & 10.5 & 1.7 & 1.7 \\
\hline \multirow[t]{2}{*}{ Maize meal porridge } & $4-12$ & 6.0 & 12.0 & 30.0 & 24.0 & 28.0 \\
\hline & $12-24$ & 0.0 & 28.1 & 52.6 & 10.5 & 8.8 \\
\hline \multirow[t]{2}{*}{ Nutromeal* $^{*}$} & $4-12$ & 84.0 & & & & 16.0 \\
\hline & $12-24$ & 96.5 & & & & 3.5 \\
\hline \multirow[t]{2}{*}{ Rice } & $4-12$ & & 54.0 & 12.0 & 4.0 & 30.0 \\
\hline & $12-24$ & & 75.4 & 15.8 & 7.0 & 1.7 \\
\hline \multirow[t]{2}{*}{ Rice and beans } & $4-12$ & & 62.0 & 12.0 & & 26.0 \\
\hline & $12-24$ & & 86.0 & 12.3 & & 1.7 \\
\hline \multirow[t]{2}{*}{ Potatoes } & 4-12 & 0.0 & 68.0 & 30.0 & 2.0 & 0.0 \\
\hline & $12-24$ & 1.7 & 80.7 & 12.3 & 3.5 & 1.7 \\
\hline \multicolumn{7}{|l|}{ Vegetables } \\
\hline \multirow[t]{2}{*}{ Cabbage } & $4-12$ & & & 4.0 & 8.0 & 88.0 \\
\hline & $12-24$ & & & 10.5 & 28.1 & 61.4 \\
\hline \multirow[t]{2}{*}{ Carrots } & $4-12$ & & & 2.0 & 10.0 & 88.0 \\
\hline & $12-24$ & & & 3.5 & 8.8 & 87.7 \\
\hline \multirow[t]{2}{*}{ Imifino† } & 4-12 & & 0.0 & 10.0 & 28.0 & 62.0 \\
\hline & $12-24$ & & 1.7 & 31.6 & 45.6 & 21.0 \\
\hline \multirow[t]{2}{*}{ Pumpkin } & 4-12 & & 57.1 & 34.7 & 6.1 & 2.0 \\
\hline & $12-24$ & & 71.9 & 21.0 & 5.3 & 1.7 \\
\hline \multirow[t]{2}{*}{ Spinach } & $4-12$ & & & 2.0 & 26.5 & 71.4 \\
\hline & $12-24$ & & & 1.7 & 60.3 & 37.9 \\
\hline \multirow[t]{2}{*}{ Tomatoes } & $4-12$ & & 2.0 & 14.3 & 61.2 & 22.4 \\
\hline & $12-24$ & & 1.7 & 32.8 & 60.3 & 5.2 \\
\hline \multicolumn{7}{|l|}{ Fruit } \\
\hline \multirow[t]{2}{*}{ Apple } & $4-12$ & & 0.0 & 12.2 & 28.6 & 59.2 \\
\hline & $12-24$ & & 1.7 & 17.2 & 58.6 & 22.4 \\
\hline \multirow[t]{2}{*}{ Banana } & $4-12$ & & 10.2 & 46.9 & 40.8 & 2.0 \\
\hline & $12-24$ & & 8.6 & 48.3 & 41.4 & 1.7 \\
\hline \multirow[t]{2}{*}{ Orange } & $4-12$ & & 16.3 & 71.4 & 12.2 & 0.0 \\
\hline & $12-24$ & & 19.0 & 67.2 & 10.3 & 3.4 \\
\hline
\end{tabular}

* Specially developed maize meal-based porridge (unfortified).

†A collection of various dark green leaves, eaten as a vegetable (it resembles spinach). This include leaves growing wild, and leaves from other vegetables, e.g pumpkin leaves. 
animal origin such as meat, chicken, fish and eggs were consumed either once a week or less. Liver was not consumed by infants younger than 1 year, while $15.5 \%$ of the children in the 12-24-month age category consumed liver, although seldomly. Soya products were consumed by $40 \%$ of the under-twos, although seldomly. Fruits mainly consumed were bananas and oranges. Vitamin A rich fruits such as pawpaw and yellow peaches were not consumed. Pumpkin, the only vitamin A rich food that featured prominently in the diet, was consumed at least 4 days week ${ }^{-1}$ by $57.1 \%$ and $71.9 \%$ of children in the 4-12 months and $12-24-$ month old categories, respectively.

\section{Discussion}

Nearly all mothers (99\%) initiated breastfeeding. In the $4-12$-month age category, $80 \%$ of the infants were still being breastfed at the time of the survey, while more than $40 \%$ had low serum ferritin levels. Serum ferritin is known to be 'falsely' elevated in the presence of infection ${ }^{14}$. Taking into account that only about $5 \%$ of the children appeared to have an infection (WBC $>17.7 \times 10^{9} 1^{-1}$ ) during the period of data collection, it is unlikely that the findings were influenced by infection. Term infants have adequate iron stores to maintain iron sufficiently for approximately 4 months of postnatal growth ${ }^{15}$. For most infants iron stores become depleted by the time that they are 4-6 months old $^{16}$. This stresses the importance of appropriate complementary foods.

Of concern is the introduction of water at a very young age - often during the first month after birth. The main source of drinking water is the Umgeni river which, at times, is heavily polluted. Although most mothers indicated that the water was boiled before consumption, aspects such as unhygienic feeding utensils could pose a risk for diarrhoea.

Solid foods were introduced at $3.6 \pm 0.8$ months, as compared to $2.8 \pm 0.8$ months reported previously for the same area ${ }^{17}$. Promotion of sound breastfeeding and complementary feeding practices at the community-based growth monitoring posts ${ }^{6}$ could have brought this positive shift about. As in other rural communities ${ }^{4}$, maize meal porridge was the first solid food introduced.

Qualitative dietary data reflected a diet high in carbohydrate-rich foods with infrequent intakes of food of animal origin, fruits and vegetables. The low serum retinol and ferritin levels reflect the low dietary intake of foods rich in vitamin $\mathrm{A}$ and iron. Although it is a tropical area where paw-paws are common in summer, paw-paws are not consumed by the under-twos. The effect of seasonality on fruit and vegetable intake is probably very small. Due to cost and availability, most fruits and vegetables eaten are homegrown. Foods produced locally include mostly pumpkin, imifino, maize and cabbage ${ }^{18}$. Although there are a few paw-paw trees in the area, the fruit of these trees are eaten by the adults, and not the young ones (personal observation). Oranges were the only vitamin $\mathrm{C}$ rich food consumed at least once a week by more than $50 \%$ of the children. Promoting the use of vitamin $\mathrm{C}$ rich foods such as an orange with meals could enhance iron absorption ${ }^{16}$, resulting in a better iron status of the children.

The prevalence of $37.3 \%$ of children with low serum retinol levels $\left(<20 \mu \mathrm{g} \mathrm{dl}^{-1}\right)$ reflects the national prevalence $^{3}$, and according to international criteria ${ }^{2}$, this community, as the country as a whole, has a public health problem of vitamin A deficiency. Factors other than a poor intake of vitamin A rich foods could also have contributed to the poor vitamin A status of these children.

Nearly $16 \%$ of the children had an episode of diarrhoea during the 2 weeks prior to the survey. Most of these episodes lasted for 4 or more days. It is important to note that in a previous survey in the same area diarrhoea was given as the main cause of infant deaths ${ }^{6}$. The presence of large quantities of retinol in the urine of children with acute diarrhoea and the negative association found between serum retinol concentration and the duration of diarrhoea suggested that urinary excretion of retinol may be an important contributor to vitamin A depletion ${ }^{19}$.

Anthropometric parameters are accepted, inexpensive, quick and objective health indicators ${ }^{20}$ and are related to the risk of child mortality ${ }^{21}$. Although the prevalence of stunting and underweight was lower than the national prevalence (one in four children and one in 10 children, respectively), it resembles the prevalence in the province (KwaZulu-Natal) ${ }^{3}$. The prevalence of neither stunting, underweight nor wasting reached proportions of moderate severity according to the WHO classification ${ }^{13}$. Stunting was more prevalent than either underweight or wasting. The weight-for-height distribution was comparable to the NCHS standard; the children were not wasted, and therefore not energy deficient. This, together with the poor micronutrient status of the under-twos, suggests that quality rather than quantity of dietary intake is at stake in this rural community. Poor dietary intakes of micronutrients could contribute to growth retardation. Many children in developing countries, and poor children in developed countries, become stunted during infancy as a result of inappropriate weaning practices, repeated infections and poor diet $^{22,23}$. In addition to dietary factors, frequent episodes of diarrhoea could be a contributing factor to growth retardation. It has been shown that the load of diarrhoeal diseases in early childhood has longterm consequences for height-for-age (a parameter for 
long-term nutrition $)^{24}$. The poor micronutrient status and the infrequent intake of various vitamin A and ironrich foods reflect a suboptimal diet in this community. Under these conditions the children's potential for postdiarrhoeal catch-up growth is reduced. Studies have shown that diarrhoea has sustained negative effects on growth in populations where the dietary intake is below recommended levels ${ }^{25}$.

Although the overall prevalence (15.3\%) of stunting was not as high as in many other developing countries, it should not be neglected. It has been shown that in some countries stunted children have a higher risk of overweight, with a risk ratio of 2.6 for South African children $^{26}$. According to Popkin et al., stunted children in low-income countries have little opportunity, in terms of economic conditions, lifestyles and resource availability, to become obese ${ }^{26}$. In this community (Ndunakazi), as in many other communities in South Africa, overweight is a problem in adult females ${ }^{27}$. South Africa is in a transition period and shifts in body composition because of changes in dietary and activity patterns should be anticipated as these are characteristic of transition periods.

The prevalence of $65.2 \%$ of children being anaemic is much higher than the national figure of one in five children $^{3}$. This emphasizes that values determined by only one survey, although national, cannot be extrapolated to specific geographical areas. Geographical differences in malnutrition and dietary practices should therefore be taken into consideration when planning cost-effective nutritional intervention programmes. Documentation of the nutritional status and related factors of various communities could help to target strategies to address the nutritional problems of the country.

Taking into account the poor nutritional status of the under-twos, we suggest that nutrition education and intervention programmes, as well as feeding schemes, should emphasize the quality of the diet, rather than quantity. The focus of these programmes should be to address micronutrient deficiencies through dietary and non-dietary means.

\section{Acknowledgements}

Our sincere appreciation to the South African Sugar Association for their financial contribution towards our work in the Ndunakazi area. We thank Ms MP Marais, Mr DeW Marais, and Mr EAR Harmse for their technical support; Dr MA Dhansay for his assistance in drawing blood; the Department of Haematology of the University of Natal for doing the full blood counts; Mr Michael Phungula and his team of nutrition monitors for their invaluable support and dedication to the study; and the mothers and guardians who participated in the study.

\section{References}

1 White Paper for the Transformation of the Health System in South Africa. Government Gazette 1997; 382 (17910): 8496.

2 Report of a joint WHO/UNICEF Consultation, Geneva, Switzerland, 9-11 November 1992. Indicators for Assessing Vitamin A Deficiency and their Application in Monitoring and Evaluating Intervention Programmes. Review version, May 1994, pp. 1-56.

3 The South African Vitamin A Consultative Group (SAVACG). Children Aged 6 to 71 Months in South Africa, 1994: Their Anthropometric, Vitamin A, Iron and Immunisation Status. South Africa, 1995.

4 Steyn NP, Badenhorst CJ, Nel JH, Ladzani R. Breast-feeding and weaning practices of Pedi mothers and the dietary intakes of their preschool children. S. Afr. J. Food Sci. Nutr 1993; 5: 10-13.

5 Vorster HH, Oosthuizen W, Jerling JC, Veldman FJ, Burger HM. The Nutritional Status of South Africans. A Review from the Literature. Part 1. Durban, Health Systems Trust, 1997; 19.

6 Faber M, Oelofse A, Benadé AJS. A model for a communitybased growth monitoring system. Afr. J. Health Sci. 1998; 5 $72-8$.

7 Jelliffe DB, Jelliffe EFP (eds). Anthropometry: major measurements. In: Community Nutritional Assessment, first edition. Oxford: Oxford University Press, 1989; 68-104.

8 Catignani GL, Bieri JG. Simultaneous determination of retinol and $\alpha$-tocopherol in serum or plasma by liquid chromatography. Clin. Chem. 1983; 29: 708-12.

9 Pilch SM, Senti FR (eds) Assessment of the Iron Nutritional Status of the US Population Based on Data Collected in the Second National Health and Nutrition Examination Survey, 1976-1980. Bethesda, Maryland, Life Sciences Research Office, Federation of the American Societies for Experimental Biology, 1984.

10 WHO. Iron Deficiency: Indicators for Assessment and Strategies for Prevention: WHO/Nutr/96.12. Geneva: World Health Organization, 1997.

11 Hinchliffe RF. Reference values. In: Lilleyman JS, Hann IM eds. Paediatric Haematology. New York: Churchill Livingstone, 1992; 1-22.

12 Flores H. Frequency distribution of vitamin A levels in crosssectional surveys and in surveys before and after vitamin A supplementation. In: A Brief Guide to Current Methods of Assessing Vitamin A Status. A Report of the International Vitamin A Consultative Group (IVACG). Washington DC: the Nutrition Foundation, 1993; 9-11.

13 WHO Working Group on the Use and Interpretation of Anthropometric Indicators of Nutritional Status. Bull WHO 1986; 64: 929-41.

14 Witte DL. Can serum ferritin be effectively interpreted in the presence of the acute-phase response? Clin. Chem. 1991; 37 484-5.

15 Oski FA. Iron deficiency in infancy and childhood. N. Engl.J Med. 1993; 329: 190-3.

16 Fairweather-Tait SJ. Iron in food and its availability. Acta. Paediatr. Scand. 1989; (suppl.) 1989; 361: 12-20.

17 Faber M, Oelofse A, Kriek JA, Benadé AJS. Breastfeeding and complementary feeding practices in a low socio-economic urban and a low socio-economic rural area. S. Afr. J. Food Sci. Nutr. 1997; 9: 43-51.

18 Faber M, Smuts CM, Benadé AJS. Dietary intake of primary school children in relation to food production in a rural area in KwaZulu-Natal, South Africa. Int. J. Food Sci. Nutr. (in press).

19 Alvarez JO, Salazar-Lindo E, Kohatsu J, Miranda P, Stephensen CB. Urinary excretion of retinol in children with acute diarrhoea. Am. J. Clin. Nutr. 1995; 61: 1273-6. 
20 World Health Organization. Nutrition: global surveillance through anthropometric measurement. Wkly. Epidemiol. Rec. 1987; 62: 37-8.

21 Pelletier DL. The relationship between child anthropometry and mortality in developing countries: implications for policy, programs and future research. J. Nutr. 1994; 124: 2047S-81.

22 Wiecha J, Casey V. High prevalence of overweight and short stature among Head Start children in Massachusetts. Publ. Health Rep. 1994; 109: 767.

23 Adair LS, Guilky DK. Causes of Stunting in Filipino children. Carolina Population Center, the University of North Carolina at Chapel Hill, Chapel Hill, NC, 1996.

24 Bøhler E, Bergström E. Frequent diarrhoeas in early childhood have sustained effects on the height, weight and head circumference of children in East Bhutan. Acta. Paediatr. 1996; 85: 26-30.

25 Lutter CK, Mora JO, Habicht JP, Rasmussen KM, Robson DG, Sellers SG, Super CM, Herrera MG. Nutritional supplementation: effects on stunting because of diarrhoea. Am.J. Clin. Nutr. 1989; 50: 1-8.

26 Popkin BM, Richards MK, Montiero CA. Stunting is associated with overweight in children of four nations that are undergoing the nutrition transition. J. Nutr. 1996; 126: 3009-16.

27 Vorster HH, Oosthuizen W, Jerling JC, Veldman FJ, Burger HM. The Nutritional Status of South Africans. A Review of the Literature from 1975-1996. Part 2. Durban, Health Systems Trust, 1997; 53. 